\title{
The effect of perforated polyethylene sheeting on the alighting behaviour of aphids (Hemiptera: Aphididae) and their infestation of potato crops
}

\author{
ANNE L. WILSON and L. R. TAYLOR \\ Department of Entamology, Rothamsted Experimental Station, Harpenden, Herts, UK
}

\begin{abstract}
Potato plots in southern England were covered by polyethylene sheeting perforated by $9-\mathrm{mm}$ slits that opened to permit expansion as the plants grew. The slits admitted rain and also some aphids. Covered plants received $93 \%$ less immigrant aphids than exposed plants. The greatest protection was from Myzus persicae (Sulz.) $(99 \%)$, whilst noncolonising species were reduced by $77 \%$. It is improbable that the barrier to movement presented by the polyethylene would differentiate between incoming species or that $M$. persicae, for which potato is a preferred host, would escape more readily once inside the cover. This suggests that the behavioural barrier to alighting is in response to the reflection of high wavelength light at the polyethylene surface which affected $\boldsymbol{M}$. persicae more than other species. The method has potential in protection of crops from aphids.
\end{abstract}

\section{Introduction}

One approach to the problem of crop protection from migrant aphids whilst avoiding increase in insecticide resistance, for example in Myzus persicae (Sulzer) (Sawicki et al. 1978), has been to deflect the immigrant aphid by reversing its alighting response to the balance of colour between earth and sky (Moericke, 1950; Kennedy et al., 1961) so that the aphid continues in flight instead of alighting. The longer wavelength components (yellow) in the colour of growing plants and soil are replaced by light reffected from the sky with aluminium or other similar foils used as a mulch between rows (Kring 1964 ; Smith et al., 1964 ; Heinze, 1967). Increase in the shorter wavelength components (blue) of light reflected from beneath the flying aphids disrupts their alighting behaviour. However, the effect diminishes as the plants grow and obscure the mulch (Adlerz \& Everett, 1968), and the method is not always effective for M. persicae (Fusco \& Thurston, 1970; Shands \& Simpson, 1972).

Carrying this approach a stage further, a new technique for growing plants under a slotted, transparent but reflecting, polyethylene sheet developed primarily to raise crop temperature in early spring (Anon., 1976; Lang, 1977) was investigated for its effect on aphids alighting on potatoes during 1977 and 1978 . The slots permitted the sheet to expand as the plants grew, and also admitted rain; as a result, they also admitted some immigrant aphids which, once underneath the sheet, might be discouraged from emigrating so causing aphids to accumulate on the plants. Kennedy et al. $(1959 a, b)$ and Müller $(1958,1962)$ found that even on suitable hosts, the accumulation of immigrants resulted from a preponderance of alighting over re-take- 
off of transients, which could be small or large depending on the time previously spent in flight (Taylor, 1965) and a slight change in the balance of illumination and wind speed at the plant surface could have a disproportionate effect on settling behaviour.

In the present experiments, therefore, the nett effect was investigated of the refiection from the polyethylene surface on the alighting response of potential immigrants, the mechanical barrier to movement through the perforated sheeting, and the subsequent differential effect of shelter and changed illumination on the settling behaviour of the aphids once inside the cover.

\section{Materials and methods}

The transparent polyethylene 'Xiro' used in these experiments was marketed as a weather-protection film to give earlier harvesting and increased yields. The film was perforated by $9-\mathrm{mm}$ slits in rows $3 \mathrm{~mm}$ apart so that, when stretched, the slits opened to give a fine plastic mesh (Plate $\mathrm{XA}$ ). A sheet of film $1.6 \mathrm{~m}$ wide was laid using a tractor-mounted machine, supplied by the manufacturer, that pressed the unslit borders $3-5 \mathrm{~cm}$ into the soil and consolidated the soil to hold the buried edges. The ends of sheets and some edges had to be embedded by hand in the heavy clay soil. The machine was set so that the sheet was laid loosely along the length of the covered bed and as loosely across the width as the potato ridges would allow. Thus the slits were initially closed but they were forced apart as the potato plants emerged and pushed the film upwards. Even before expansion, the slits opened under the pressure of rain water and allowed it to pass through.

\section{Preliminary trial, 1977}

A preliminary trial, on a $0 \cdot 2$-ha plot of potatoes in Great Harpenden I Field at Rothamsted with the central 26 rows of a square plot covered by polyethylene film sheeting, was on an early crop of Arran Comet because the sheet might have restricted plant growth if used later in the season. The crop was planted on 15 April, treated with a pre-emergence herbicide on $1 \mathrm{May}$, and covered between 2 and $10 \mathrm{May}$, when the first plants were already showing, to minimise the temperature effect.

The covered plants could not be examined for aphids until the sheet was finally removed. Plants in the uncovered areas on each side of the covered zone were sampled throughout the season to investigate the pattern of aphid colonisation and the effect of the covered area on adjacent plants. Because little aphid migration occurred, the experiment was prolonged by removing the polyethylene in stages between 14 June and 9 July as it began to tear. During this time, the sheet was fully extended and serious restriction of plant growth ensued.

To compare virus spread in covered and uncovered plots, progeny tubers were grown the following spring. A hundred tubers were taken from strips exposed before and after 30 June, and 50 tubers from each uncovered plot on 15 July. Each tuber was halved, each half grown separately, and the resulting plants were assessed visually.

Four assessments of yield were made, each of 6 rows $\times 46 \mathrm{~m}\left(156^{\prime}\right)$. One measurement was taken from each uncovered flank and one each from the covered areas exposed before and after 30 June.

\section{Replicated trial in 1978 with two planting dates}

Interest now centred on the aphids. Twelve plots in six randomised pairs, each of a covered and an exposed control 15.6 $\times 15.3 \mathrm{~m}$, of Pentland Crown main-crop potatoes resistant to potato virus $Y$ were grown on Highfield IV at Rothamsted. Three pairs of plots were planted early to be exposed to normal immigration, and three pairs late to be exposed to increased numbers of migrant aphids whilst the plants were small and the covers still in place on the experimental plots. The six early plots were planted on 25 April, the sheet laid on 17 May and the plants examined from 9 to 21 June; the six late plots were planted on 21 June, the sheet laid on 29 June, and the 
plants examined from 17 to 21 July. The aphids were counted at a later stage of crop development on the early-planted plots.

The sheet was removed from one row of 40 plants at a time and plants examined immediately for aphids because removing sheets created a new edge to the plots. Most aphid counts were done by detailed visual examination of the whole plant, but aphids on larger plants were collected by threshing over a white tray (Hille Ris Lambers, 1972). About 500 plants were examined from each covered plot and 180 plants from each control. Only two of the three pairs of late-planted plots were examined for aphids.

Yield measurements were taken on four rows $(61.2 \mathrm{~m})$ from each plot.

\section{Results}

\section{Preliminary trial, 1977}

The covered area had the appearance of a sheet of water and, as the foil was loosely laid it produced a shimmering effect which enhanced reflection of light (Plate X). Covered plants grew more rapidly than those outside until about mid-June when the polyethylene was fully extended. Fewer potato aphids occurred on covered plants especially nymphs and apterous adults. Macrosiphum euphorbiae (Thomas) was the most abundant potato aphid in 1977, and alatae of this species were much less common under the polyethylene sheet (mean $7 \cdot 6 / 100$ plants) than on exposed plants (59.0/100 plants). The proportional reduction in alate Myzus persicae was greater, but the numbers were less $(1.8$ and 17.9 , respectively) and the result inconclusive. Similarly, the proportions of nymphs + apterous adults were smaller under the polyethylene sheeting for both $M$. persicae (12.4 and 236.0) and Macrosiphum euphorbiae (32.4 and 462.0). In contrast, alatae of non-colonising species, mainly Brachycaudus helichrysi (Kaltenbach), Cavariella aegopodii (Scopoli) and Phorodon humuli (Schrank), were slightly more common on the covered plants than outside (32.4 and 20.5$)$.

Until mid-June, when the first sheets were removed, only very small aphid infestations occurred on the uncovered flanks. Accumulated counts in three zones, rows 1-6 (adjacent to the covered plots), rows 7-30 (centres of the uncovered plots) and rows 31-36 farthest from the covered plots, showed fewest aphids in the zone adjacent to the polyethylene: rows $1-6,3.6$ alatae and 6.3 others; rows $7-30,10.9$ alatae and 27.5 others; rows $31-36,10 \cdot 1$ alatae and 12.8 others. The result is not significant but suggests that aphids may have been deflected by the sheets.

None of the progeny tubers subsequently grown in the greenhouse produced virusinfested plants.

Some reduction in yield occurred in covered potatoes; it was greater in plants

TABLE I. Differences between plots, planting dates and polyethylene protection in numbers of aphids in 1978

\begin{tabular}{|c|c|c|c|c|c|}
\hline \multirow{2}{*}{$\begin{array}{l}\text { Planting } \\
\text { date }\end{array}$} & \multirow{2}{*}{$\begin{array}{l}\text { Plot } \\
\text { no. }\end{array}$} & \multirow[b]{2}{*}{ Treatment } & \multicolumn{3}{|c|}{ Mean no. of aphids (all species) $/ 100$ plants } \\
\hline & & & Alatae & Apterae + nymphs & Total aphids \\
\hline \multirow[t]{5}{*}{ Early (25 April) } & 1 & $\begin{array}{l}\text { Covered } \\
\text { Uncovered }\end{array}$ & $\begin{array}{r}14.0 \\
180.4\end{array}$ & $\begin{array}{r}8.1 \\
749.7\end{array}$ & $\begin{array}{r}22 \cdot 0 \\
930 \cdot 2\end{array}$ \\
\hline & 2 & Covered & 22.9 & $39 \cdot 1$ & 62.0 \\
\hline & & Uncovered & $165 \cdot 7$ & $1211 \cdot 2$ & $1377 \cdot 0$ \\
\hline & 3 & Covered & $18 \cdot 0$ & $9 \cdot 5$ & $27 \cdot 5$ \\
\hline & & Uncovered & $158 \cdot 7$ & $669 \cdot 5$ & $828 \cdot 3$ \\
\hline \multirow{6}{*}{ Late (21 June) } & 4 & Covered & $5 \cdot 1$ & $15 \cdot 3$ & 20.4 \\
\hline & & Uncovered & 214.9 & $144 \cdot 7$ & $359 \cdot 6$ \\
\hline & 5 & Covered & $3 \cdot 8$ & $6 \cdot 3$ & $10 \cdot 0$ \\
\hline & & Uncovered & $229 \cdot 3$ & $135 \cdot 0$ & $364 \cdot 3$ \\
\hline & All plots & Covered & 12.7 & $15 \cdot 6$ & 28.4 \\
\hline & & Uncovered & $189 \cdot 8$ & $582 \cdot 1$ & $771 \cdot 9$ \\
\hline
\end{tabular}

Late-planted plot No. 6 was lost due to accidental damage. 


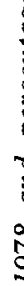

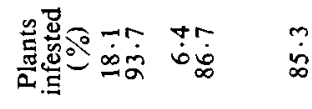

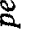

焉

$\stackrel{\infty}{2}$

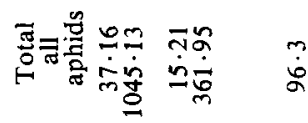

$\frac{2}{2}$

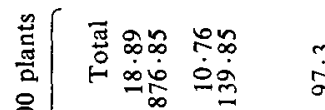

8

2

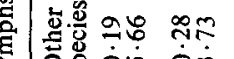

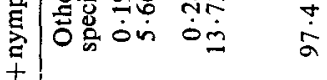

岁

$\$$

है

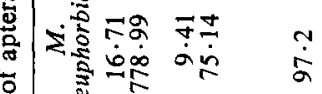

这

3

$\stackrel{0}{5}$

$\stackrel{m}{\infty}$

$\ddot{\dot{\sigma}}$

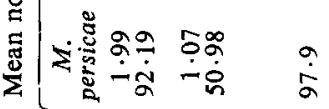

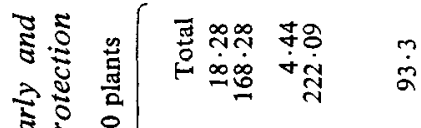

5

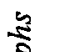

8

บั:

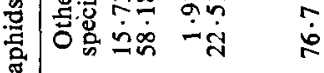

ई

离

ชิ

$\stackrel{2}{4}$

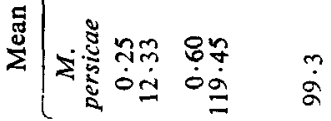

$\frac{8}{2}$

$+$

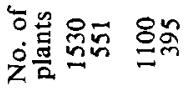

总

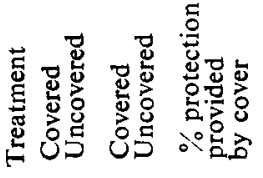

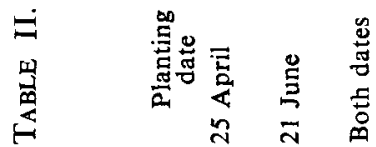


covered longer because the cover retarded plant growth: mean yield 20.9 tonnes/ha on uncovered plots, 20.1 tonnes on those exposed early and 18.4 tonnes on those exposed late.

\section{Replicated trial, 1978}

Aphid numbers were strikingly and significantly reduced on all covered plots, compared with uncovered plots (Table I). Before the sheets were removed from earlyplanted plots, few nymphs were deposited, although aphid infestations were developing on uncovered plots. On late-planted plots, infestations on uncovered plots were less advanced and the difference between covered and uncovered plants less marked; the difference for alatae was less than for apterae but still very great.

Most alatae under cover on early-planted plots were species that do not normally colonise potatoes $(15 \cdot 73 / 100$ plants, as compared with $0.25+2 \cdot 30 / 100$ plants for those that normally colonise them (Table II)) ; most of these were $B$. helichrysi which may transmit virus and was recorded in unusually large numbers in the Rothamsted $12 \cdot 2-\mathrm{m}$ suction trap during the period when the early plots were covered (Table III).

The reduction in aphids in 1978, expressed as a percentage of the aphids on uncovered plots (Table II) was more than $96 \%$, although only $77 \%$ of non-potato aphid alatae were excluded. The greatest reduction (99\%) was in alate Myzus persicae. The aerial density of this species remained low in the early part of the season (Taylor \& French, 1979) so that clearest results were obtained on the late-planted plots.

TABLE III. Aerial density (numbers $/ 10^{6} \mathrm{~m}^{3}$ of air) of alate aphids at $1 \cdot 2$ and $12 \cdot 2 m$ above the ground in 1978

\begin{tabular}{|c|c|c|c|c|c|c|c|c|}
\hline un & \multicolumn{2}{|c|}{$\begin{array}{c}\text { persicae } \\
1.2 \mathrm{~m} \quad 12.2 \mathrm{~m}\end{array}$} & \multicolumn{2}{|c|}{$1.2 \mathrm{~m} 12.2 \mathrm{~m}$} & \multicolumn{2}{|c|}{$1.2 \mathrm{~m} 12.2 \mathrm{~m}$} & \multicolumn{2}{|c|}{$1.2 \mathrm{~m} 12.2 \mathrm{~m}$} \\
\hline $\begin{array}{l}\text { May- } 21 \text { June } \\
\text { Total catch } \\
\text { Aerial density }\end{array}$ & $\begin{array}{l}1 \\
2 \cdot 2\end{array}$ & $\begin{array}{l}1 \\
0.6\end{array}$ & $\begin{array}{l}3 \\
6.7\end{array}$ & $\begin{array}{l}6 \\
3.7\end{array}$ & $\begin{array}{r}630 \\
1399\end{array}$ & $\begin{array}{l}746 \\
483\end{array}$ & $\begin{array}{l}433 \\
961\end{array}$ & $\begin{array}{l}932 \\
603\end{array}$ \\
\hline $\begin{array}{l}29 \text { June-2J luly } \\
\text { Total catch } \\
\text { Aerial density }\end{array}$ & $\begin{array}{c}4 \\
13 \cdot 9\end{array}$ & $\begin{array}{l}3 \\
2.9\end{array}$ & $\begin{array}{c}4 \\
13 \cdot 9\end{array}$ & $\begin{array}{l}7 \\
6 \cdot 7\end{array}$ & $\begin{array}{r}46 \\
160\end{array}$ & $\begin{array}{l}57 \\
55\end{array}$ & $\begin{array}{r}958 \\
3361\end{array}$ & $\begin{array}{l}2478 \\
2383\end{array}$ \\
\hline
\end{tabular}

As in 1977, there was little virus and no difference was found between treatments. Yield was reduced on covered plots by 5 tonnes/ha for the early planting (uncovered 40.9 and covered 35.9 ) and by 0.6 tonnes/ha for the late planting (26.5 and 25.9). Covering with polyethylene may be detrimental to normal growth in main-crop potatoes such as Pentland Crown, a tall, erect variety, which quickly pushed the cover to full stretch. The sheeting on late-planted plots was removed only 2-3 weeks after crop emergence, but the longer period of cover on the early-planted plots, 3-5 weeks, affected plant growth, and the plants were slightly etiolated.

\section{Discussion}

In 1977 and 1978, perforated polyethylene film greatly reduced alighting by migrant aphids and also reduced subsequent colonisation of the crop by the potato aphid species. It was most effective during the early stages of plant growth and decreased as the growing plants pressed against the sheet and opened the slits.

Winged aphids found in crop inspections represent the ephemeral differences between rates of alighting and departure and, except during continuous recording, most aphids leave unseen. Probing is essential for host-plant identification, but previous flight experience affects the settling responses and departure is common even from suitable hosts as part of the dispersive host-finding behaviour that causes the 
great seasonal redistribution of populations, in $M$. persicae for example (Taylor, $1977 a, b)$.

The polyethylene film sheeting presents a sequence of barriers to normal hostfinding behaviour. Visual deflection of alighting flight may be effective from a metre or more. It should be strongest in those aphids most strongly attracted to yellow. Closer inspection of the film may lead to rejection of the physical surface. Few aphids are likely to fly straight through the slits because of their shape (Plate $\mathrm{X} A$ ). When the temperature is higher inside the cover than outside, there may be a slight nett outflow of air. If the aphid alights on the film it may probe the upper surface and is then most likely to take off upwards (Heathcote, 1968). However, some may walk through the slits in the sheet and take off downward or walk on to the plant. Probing the plant will result in some selection in favour of potato aphids, but aphids that take off again will meet the film from below. Again, few will fly straight through, although the airflow may now sometimes assist them a little. Alighting leads to a repetition of the same cycle. This will tend to reinforce settling behaviour in potato aphids and the light response in non-potato aphids. There will be a nett delay in departure which could account for the slight increase in $B$. helichrysi, $C$. aegopodii and $P$. humuli found in the preliminary experiment, but on balance one might expect there to be a relative increase in accumulation of potato aphids on the plant.

In practice the reverse occurred (Table II). Relatively more potato aphids were excluded, and $\boldsymbol{M}$. persicae was excluded more effectively than the large Macrosiphum euphorbiae, eliminating any likelihood that the film presented a purely mechanical barrier. Also, in the preliminary experiment, fewer aphids were found on uncovered plants near to the sheet than further away. All this evidence seems to point to the differential deflection of species before reaching the film as a major, but not necessarily the only, factor. Certainly its appearance to human eyes and to the camera is striking (Plate XB), and any such repellant effect was greatest in Myzus persicae, which is strongly attracted to yellow (Eastop, 1955). The experiments did not enable the relative importance of the behavioural mechanisms to be measured. However, protection on covered potatoes was higher in M. persicae and Macrosiphum euphorbiae than in other species (Table II), despite the prevalence of other species in the air (Table III) as measured by the suction trap at $12 \cdot 2 \mathrm{~m}$.

If the covers discouraged alighting or delayed the departure of aphids that had alighted on a plant, the difference in numbers of winged aphids found on covered and uncovered plots could represent more alightings on uncovered plants. Thus, protection from virus could exceed the estimated protection from aphids (Table I); but the risk of virus spread could be increased if restless virulent migrants were trapped inside. However, nymphs found under the sheet usually occurred on the same plant as the winged parent, or occasionally on an adjacent plant, suggesting that potato aphids did not move much between plants under the sheet despite the shelter provided. The extent of aphid movement and virus spread inside the cover remains to be investigated.

Yield loss due to aphid feeding was avoided by the polyethylene cover, but populations were not high and this effect was outweighed by the loss due to stunting of normal growth. Deformation of the plants could be minimised with less erect cultivars and by removing the film as soon as it is fully extended. However, if aerial densities of aphids are still high at this time, uncovering the plants should be postponed. Reference to the Rothamsted. Insect Survey weekly bulletin of the abundance and geographical distribution of migrating aphids might help in deciding when to do this (Taylor, 1974, 1977a).

Applying herbicide and laying the polyethylene sheet must be done before the crop emerges, when the weather is calm and the ground firm enough to take machinery. Removing the sheeting is time-consuming if done by hand, so that it is only practical to cover small areas of crop with current techniques.

The future of perforated sheeting as a protection of any crop from aphids depends 
on it proving to be practical and economic in relation to the value of the crop. Maincrop potato varieties being grown for seed could be protected from aphids for only two to three weeks after crop emergence with the films currently available. It is during this time that the crop is most attractive to migrant aphids and the plants most susceptible to virus (Cadman \& Chambers, 1960), but crops could be covered throughout the growing season by a sheet capable of greater extension by being pleated when first laid. If any early crop is covered to speed-up development and bring forward the date of harvest, protection from aphids would be an added bonus when the spring migration is early. The sheeting could be of most use to farmers who wish to grow their own seed in areas where the activity of viruliferous aphids normally makes this inadvisable. A considerable proportion of potato acreage in Britain, for example, is planted with once-grown seed. Improvement in the quality of this seed by the use of protective films could make a contribution to the health of the potato crop, and any slight reduction in yield caused by retention of the film would be of less consequence than in ware crops.

More extensive local trials are needed before the value of this approach is confirmed in any crop, but its potential could be considerable for small plots of high value crops, such as seed crops, in areas of high aphid or virus risk.

\section{Acknowledgements}

We are grateful to the Potato Marketing Board for financial support.

\section{References}

ANON. (1976). Growing potatoes before anyone else.-Br. Farm. \& Stockbreeder 26.6.76, p. 33. Adlerz, W. C. \& Everetr, P. H. (1968). Aluminium foil and white polyethylene mulches to repel aphids and control watermelon mosaic.-J. econ. Ent. 61, 1276-1279.

Cadman, C. H. \& Chambers, J. (1960). Factors affecting the spread of aphid-borne viruses in potato in eastern Scotland. III. Effects of planting date, roguing and age of crop on the spread of potato leaf-roll and Y viruses.-Ann. appl. Biol. 48, 729-738.

Eastop, V. F. (1955). Selection of aphid species by different kinds of insect traps.-Nature, Lond. 176, 936.

Fusco, R. A. \& Thurston, R. (1970). Effect of coloured foils on green peach aphid infestations of burley tobacco.-Tob. Sci. 14, 126-127.

Heatнсоте, G. D. (1968). Protection of sugar beet stecklings against aphids and viruses by cover crops and aluminium foil.-Pl. Path. 17, 158-161.

HeInZE, K. (1967). Die Vergilbungskrankheit der Kohl- und Wasserrübe als Krankheitsursache auf Zierpflanzen.-Mitt. biol. BundAnst. Ld- u. Forstw. 121, 132-139.

Hille Ris Lambers, D. (1971). Aphids: their life cycles and their role as virus vectors.pp. 36-56 in de Bokx, J. A. (Ed.). Viruses of potatoes and seed potato production.232 pp. Wageningen, Centre for Agricultural Publishing and Documentation.

Kennedy, J. S., Booth, C. O. \& Kershaw, W. J. S. (1959a). Host finding by aphids in the field. I. Gynoparae of Myzus persicae (Sulzer).-Ann. appl. Biol. 47, 410-423.

KenNedy, J. S., Booth, C. O. \& Kershaw, W. J. S. (1959b). Host finding by aphids in the field. II. Aphis fabae Scop. (gynoparae) and Brevicoryne brassicae L.; with a re-appraisal of the role of host-finding behaviour in virus spread.-Ann. appl. Biol. 47, 424-444.

Kennedy, J. S., Booth, C. O. \& Kershaw, W. J. S. (1961). Host finding by aphids in the field. III. Visual attraction.-Ann. A ppl. Biol. 49, 1-21.

Kring, J. B. (1964). New ways to repel aphids.-Front. Pl. Sci. 17, 6-7.

LANG, H. (1977). Folieneinsatz im zünftigen Frühkartoffelanbau.-Kartoffelbau 28, 10-13.

MoEricke, V. (1950). Über das Farbensehen der Pfirsichblattlaus (Myzodes persicae Sulz.).Z. Tierpsychol. 7, 265-274.

MÜller, H. J. (1958). The behaviour of Aphis fabae in selecting its host plants, especially different varieties of Vicia faba.-Entomologia exp. appl. 1, 66-72.

MülleR, H. J. (1962). Über die Ursachen der unterschiedlichen Resistenz von Vicia faba L. gegenüber der Bohnenblattlaus, Aphis (Doralis) fabae Scop. VIII. Das Verhalten geflügelter Bohnenläuse nach der Landung auf Wirten und Nichtwirten.-Entomologia exp. appl. 5, 189-210. 
Sawicki, R. M., Devonshire, A. L., Rice, A. D., Moores, G. D., Petzing, S. M. \& Cameron, A. (1978). The detection and distribution of organophosphorus and carbamate insecticide-resistant Myzus persicae (Sulz.) in Britain in 1976.-Pestic. Sci. 9, 189-201.

Shands, W. A. \& Simpson, G. W. (1972). Effects of aluminium foil mulches upon abundance of aphids on, and yield of potatoes in northeastern Maine.-J. econ. Ent. 65, 507510.

Smith, F. F., Johnson, G. V., KahN, R. P. \& BING, A. (1964). Repellency of reflective aluminium to transient aphid virus-vectors.-Phytopathology 54, 748.

TAYLOR, L. R. (1965). Flight behaviour and aphid migration.-Proc. N, cent. Brch Ent. Soc. Amer. 20, 9-19.

TAYLOR, L. R. (1974). Monitoring change in the distribution and abundance of insects.Rep. Rothamsted exp. Sin 1973, Part 2, 202-239.

TAYLOR, L. R. (1977a). Aphid forecasting and the Rothamsted Insect Survey.-Jl R. agric. Soc. 138, 75-97.

TAYLOR, L. R. (1977b). Migration and the spatial dynamics of an aphid, Myzus persicae.J. Anim. Ecol. 46, 411-423.

TAYLOR, L. R. \& FRENCH, R. A. (1979). Rothamsted Insect Survey. Tenth annual summary. -Rep. Rothamsted exp. Stn 1978, Part 2, 137-173.

(Received 11 December 1980)

(C) Commonwealth Agricultural Bureaux, 1981 

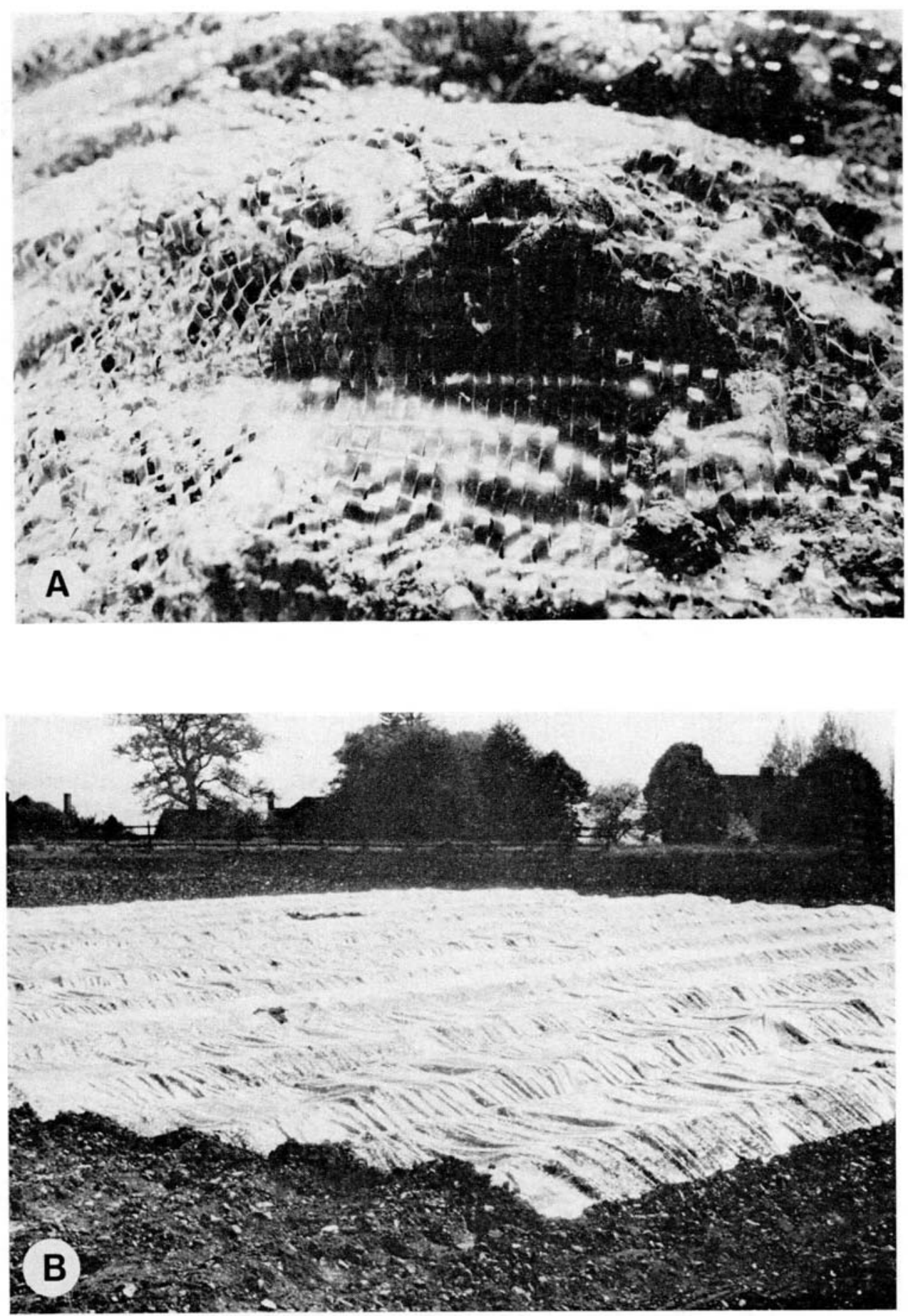

A. The slotted polyethylene sheet opens under rain pressure or as plants grow to give a mesh through which aphids can enter.

B. The flexible sheeting reflects light and shimmers like water in a slight breeze. 